\title{
University Teaching Characteristics and Reforms in Information Network Era-from the Perspective of Information Network
}

\author{
Shujuan $\mathrm{Wu}^{1, \mathrm{a}}$, Honggang $\mathrm{Yan}^{2, \mathrm{~b}}$ \\ ${ }^{1}$ Research Institute for University Development of Yangtze University, Jingzhou, 434023, China \\ ${ }^{2}$ Research Institute for University Development of Yangtze University, Jingzhou, 434023, China \\ a email: jks@yangtzeu.edu.cn, bemail:979354846@qq.com
}

Keywords: Sinformation network, Teaching reform, Education quality

\begin{abstract}
There is no doubt that the application of information technology in education has brought a huge impact on the traditional teaching. Understanding the characteristics and problems of teaching in the information network era, and deepening the reform of teaching contents and methods, which two are of great importance to enhance the quality of personnel training in China.
\end{abstract}

21st century is an era full of knowledge and information, which has brought tremendous influence on all aspects of people's lives and works. Education as a part of the social system is naturally influenced by information. Knowing the characteristics of the information network era, analyzing the university' s opportunities and challenges brought by the information network age have important practical effect on deepening the university teaching reform.Design of the Chip Kick Mechanics

\section{Connotation and characteristics of information network}

Information network is a dynamic process that integrates various resources and provides the resource sharing and information exchange for online users with computer technology, network technology and remote communication technology. The features of information network can be summarized as "three and four". The so-called "three" means: intelligent, electronic and global; the so-called "four" means: efficient, open, integrated and interactive. [1]

\section{II.University theaching features in information network era}

\section{A. Knowledge carriers: from two dimensional to three-dimensional}

The traditional teaching model is an indoctrination teaching basing on teacher, textbook and classroom and the only knowledge carrier is books. With the development of information networks, Media diversity enriches knowledge carriers including sound, image, animation, electronic text, and others ranging from the static to the dynamic. The chalk and blackboard teaching model change into the based on practice teaching mode [2].

B. Teaching form: from linear to interactive

Traditional teaching form is linear. The application of information network technology in the field of education breaks the original established pattern and turns the singularity to diversification. This kind of interactive teaching promotes students to enter the teaching center and truly be integrated into teaching.

\section{Teaching resources: from scattered to integrative}

Efficiency and openness of the information networks make teaching more convenient. The openness of the network information also turns the teaching content from the only textbook to all aspects of society. Meanwhile, the comprehensive network provides us some convenient conditions to obtain integrate resources.

D. Teaching space: from physical to virtual

Traditional teaching and learning lack flexibility because of limited space and time. The 
establishment of the teaching network platform extends traditional teaching space and makes the teaching perspective become wider, broader and more interactive, let the original teaching space extend from the entity classroom to the broad network virtual space where educational resources can be shared across geographies, time and space.

\section{E. Teaching Philosophy: From Teacher Center to the Student Center}

Under the traditional teaching mode, the teachers as the carrier and the owners of knowledge, which is a single instillation? There is no doubt to stifle students' innovation and self-learning ability although students can learn the systematic knowledge. Extensive applications of information network in the field of education provide a platform for students with entering the center from the edge of the teaching. The teachers no longer stand in the center of the teaching as a knowledge tool, but as a guide to encourage students to innovate and explore. As a consequence, this kind of teaching mode that the teachers are leading and the students are the subject of this cognitive learning is formed truly.

\section{University teaching problems in network information era}

\section{A. Pay attention to teaching form but overlook teaching effectiveness}

Education information network pays too much emphasis on form innovation and expansion of teaching, which overlooking effectiveness of teaching and students' thinking ability. Formalized classroom teaching inadvertently induce teachers to put the modernization of teaching methods in an important position, and let teaching activities deviating from teaching objectives and teaching effectiveness considerations. Whether the students are able to effectively absorb the know ledges, and cultivate creative thinking, which are replaced by the formal teaching.

\section{B. Despise equipment utilization rate, pursuing just advanced equipment}

Information network education is based on the complete equipments. Equipment is an essential precondition of the realization of the information network [3]. The high-performance advanced equipment is not necessary can improve the teaching quality, and equipment utilization rate must be considered. However, the use of software resources or the use of hardware facilities is not reasonable and sufficient to a certain degree. There is a considerable number of the school which blindly chases advanced equipment, ignoring the true efficiency in the use of the equipment.

\section{Rely too much on multimedia teaching aids, losing traditional teaching skills}

Information network education brings convenience to teaching, however, which is kidnapping a group of weak self-disciplined teachers who are accustomed to rely on the network convenience while ignoring their own traditional teaching skills training. The abundance and availability of network information resources allow teachers to prepare class simply, easily and conveniently instead of delving into the innovation of teaching means and methods.

\section{Focuses on innovative education, ignoring emotional education}

At traditional classroom, the emotion exchange and communication between teachers and students is relatively frequent and casual. As a result, it is easy to form a harmonious learning atmosphere and the relationship between teachers and students becomes closely. However, with the using of information technology like mouse and keyboard in teaching process, the distance between teachers and students are broadened. With the encouragement of innovation and the philosophy of improving students' awareness of innovation, teachers focus more on cultivating innovative consciousness, and easily ignoring emotional interaction.

\section{University teaching reform in the information network era}

Information technology has become the catalyst way to school teaching reform. [4]How to use the positive impacts and overcome the negative effects that network information have brought, deepening the teaching content, means, ways of reforms, improving the quality of talent cultivation are the problems which modern university must be seriously considered and solved.

\section{A. Change teaching philosophy and optimize classroom teaching design}

In the age of information network, under the situation of personnel training diversity 
requirements, and comprehensive and abundance teaching resources, teachers are required to pay attention to the teaching objectives, content design, and utilization of teaching resources. The cultivate students "sense of self", "competitive" and "innovation consciousness". [5]

\section{B. Strengthen information technology training to improve teachers' modern teaching ability}

Because of lacking the training of modern information technology skills, some university teachers, especially middle-aged teachers, are not good at using multimedia technology. They still used blackboard-chalk model. They can not teach students to use the advanced equipments and technologies, which also led teaching resources can not be effectively utilized, resulting in a waste of resources. In order to adapt to the modern information education requirements, universities should provide trainings of teacher-related information technology teaching skills, so as to enhance the teachers' skills, make teachers more reasonable to using rich multimedia resources for teaching.

C. Using information network platform to cultivate and improve students' comprehensive quality and capacity

It is very important to make full use of information network platform and resources to develop students' self-learning ability, information gathering capabilities, collaborative innovation capacity as well as problem analysis and solving ability. Good self-learning ability is the premise to ensure students to progress continually in the information age. Information collected ability is not only an integral part of social quality, but also a powerful guarantee to screen and absorb knowledge. Collaborative innovation ability is the inevitable requirement of the team awareness for students in a learning society. What's more, it is essential equipment for students to adapt to the society. The ability to analyze and solve problems, of course, becomes the best detection to check learning skills and quality.

D. Change teaching methods to combine organic combination multi-media technology with emotional teaching excellently

The organic combination between multimedia and emotion teaching, guarantying the advance of means and efficiency of emotion, which is the essence of network information applied into the teaching. In the information network era, in order to enhance the quality of teaching, teachers are not only required for obtaining advanced teaching philosophy and methods, but also for obtaining enriched teaching emotion and scientific teaching methods. Under the guidance of the advanced and scientific educational philosophy, combing the educational information network learning with the updating modern educational concepts is not only the objective needs of the educational information era, but also the responsibility of teachers.

Being faced with the information wave impact, the traditional teaching must undergo great change. It is desperate for contemporary university to make full use of modern educational technology, to effectively integrate all kinds of educational resources, to speed up the teaching content and methods reform, and to constantly improve the quality of teaching.

\section{References}

[1] W. Liu. Information Network and Contemporary Chinese Political Development. Huazhong Normal University: Huazhong Normal University Political Science Research Institute pp, 6-8.2005 [2]G.P.Yuan, G.L.Wang,” The modern education technology and quality education”, Journal of occupation education.pp, 85.2004.

[3] K.K. He, W.G. Li. "Educational technology”. Beijing: Beijing Normal University Press, pp, 384-386, 2008.

[4]Z.G. Yuan. "Modern Educational Technology - Information-Based Education”. Beijing: Education Science Press, 2002.

[5] Y.H. Li,” Development of Educational Technology Affects the Modernization of Education”. Tel Educational Research, (6)1999. 